УГОЛОВНО-ПРОЦЕССУАЛЬНЫЕ МЕРЫ ПРОТИВОДЕЙСТВИЯ ПРЕСТУПНОСТИ

CRIMINALLY-REMEDIAL MEASURES OF CRIME FIGHTING

удк 343.141

DOI 10.17150/2500-4255.2017.11(3).587-595

\title{
ИНФОРМАЦИОННЫЕ ТЕХНОЛОГИИ В РЕШЕНИИ УГОЛОВНО-ПРОЦЕССУАЛЬНЫХ ПРОБАЕМ
}

\author{
С.В. Зуев, Е.В. Никитин \\ Южно-Уральский государственный университет (национальный исследовательский университет), \\ 2. Челябинск, Российская Федерация
}

\author{
Информация о статье \\ Дата поступления \\ 14 июня 2016 г. \\ Дата принятия в печать \\ 25 июня 2017 г. \\ Дата онлайн-размещения \\ 29 сентября 2017 г. \\ Ключевые слова \\ Информация; электронные \\ доказательства; электронное \\ уголовное дело; электронные \\ носители информации; алгоритмы; \\ приговор
}

\begin{abstract}
Аннотация. Рассматривая современные информационные технологии, авторы приходят к выводу о том, что уголовное судопроизводство существенно отстает от использования в доказывании электронных технических средств, а также программного обеспечения при вынесении итоговых судебных решений. Утверждается, что порядок обращения с электронными доказательствами в действующем уголовно-процессуальном законодательстве не находит должного правового регулирования. Электронное уголовное дело может успешно заменить традиционное бумажное производство. Это позволит улучшить качество расследования преступлений, снизить риск возможной фальсификации доказательств, облегчить проверку материалов уголовного дела, сократить документооборот, а значит, и сроки уголовного производства. Отмечается, что обращение с электронными материалами дела приведет к значительному упрощению процедуры ознакомления с ними. Электронное уголовное дело обеспечит сохранность доказательств на длительный период. Авторы считают, что широкое использование электронных средств фиксации при производстве процессуальных действий во многом упростит их проведение, обеспечит полноту и убедительность доказательств. Для этого электронная информация должна быть признана самостоятельным видом доказательств. Применение электронной подписи обеспечит соблюдение прав и законных интересов участников уголовного судопроизводства, упростит электронный документооборот. Алгоритмизация принятия решений по квалификации преступлений, по мнению авторов, даст дополнительный инструментарий проверки судебных решений на беспристрастность, обоснованность выводов, всесторонность и полноту исследованных доказательств. Привлечение математических методов обработки больших массивов информации позволит устанавливать влияние вынесенных приговоров на восстановительную (компенсаторную) функцию права, выявлять региональные особенности вынесения приговоров и соотносить их с принципом законности, оценивать эффективность приговоров по конечному результату их действия с точки зрения ценности и полезности.
\end{abstract}

\section{INFORMATION TECHNOLOGIES IN SOLVING CRIMINAL PROCEDURE PROBLEMS}

\author{
Sergey V. Zuev, Evgeny V. Nikitin
}

South Ural State University (National Research University), Chelyabinsk, the Russian Federation

\begin{tabular}{|c|c|}
\hline & Article info \\
\hline & $\begin{array}{l}\text { Received } \\
2016 \text { June } 14\end{array}$ \\
\hline & $\begin{array}{l}\text { Accepted } \\
2017 \text { June } 25\end{array}$ \\
\hline & $\begin{array}{l}\text { Available online } \\
2017 \text { September } 29\end{array}$ \\
\hline
\end{tabular}

Russian Journal of Criminology, 2017, vol. 11, no. 3, pp. 587-595

\begin{abstract}
Having analyzed modern information technologies, the authors conclude that criminal court procedures lag behind in the use of modern IT devices for the process of proofing and in the use of software in final adjudicating. They claim that the procedure of dealing with electronic proof is not duly legally regulated in current criminal procedure legislation. An electronic criminal case can successfully substitute the traditional paper records. This will improve the quality of crime investigation, reduce the risk of possible falsification of proofs, simplify the checking of criminal cases' materials, reduce the circulation of documents and, consequently, the time spent on criminal procedures. The authors stress that the use of electronic materials will greatly simplify the procedure of studying them. An electronic criminal case will ensure the preservation of proofs over a long period of time. They believe that a
\end{abstract}




\section{Keywords}

Information; electronic proof; electronic proof; electronic criminal case; electronic storage devices; algorithms; sentence wide use of electronic media in procedural actions will considerably simplify them while making the proofs comprehensive and persuasive. To achieve this, electronic information should be recognized as an independent type of proof. The use of an electronic signature will ensure the observance of rights and lawful interests of criminal court procedure participants; it will also simplify electronic circulation of documents. The algorithmization of making decisions regarding crime qualification, in their opinion, will act as an additional instrument for checking court decisions for impartiality, validity of conclusions, comprehensive and complete character of investigated proofs. The use of mathematical methods for processing large volumes of information will allow to determine the influence of sentences on the rehabilitative (compensatory) function of law, to identify the regional specifics of sentencing and correlate them with the principle of lawfulness, to evaluate the effectiveness of sentences based on their final effect from the standpoint of value and use.
Современное общество отличается повсеместным использованием информационных телекоммуникационных технологий. Это характерно как для криминальной стороны жизни, так и для правоохранительной деятельности в противодействии преступности. Исследователи отмечают, что в сфере информационных технологий появляются новые преступления, такие как нарушение целостности, доступности и конфиденциальности электронных данных, объектом которых выступают охраняемые законом новые интересы, возникшие в связи с развитием информационных технологий. Это так называемые компьютерные преступления [1]. Кроме того, интернет-ресурсы все чаще выступают средством общения соучастников преступлений (сбыт наркотических средств и психотропных веществ, совершение различного рода хищений чужого имущества, проявления экстремизма и т.д.). Глобальные информационные сети используются для совершения деяний, ответственность за которые предусмотрена уголовным законодательством многих государств [2, р. 18].

В нашем все более цифровом обществе потребители цифровых средств массовой информации проводят огромное количество времени в Интернете. Как и в любой среде, в Сети всегда есть доля пользователей, которые стремятся обнаружить слабые места в системе или, возможно, максимизировать личную выгоду за счет других. В США появление хакерства выдвинуло проблему киберпреступности на первый план [3, р. 242].

В ответ на высокотехнологичные криминальные вызовы обществу и государству правоохранительные органы и суды во всех странах включены в процесс компьютеризации и широкого использования информационных технологий [4]. Вместе с тем необходимо признать, что действующее российское уголовное судопроизводство не в полной мере отвечает современно- му уровню развития науки и техники. Деятельность, направленная на установление факта наличия (или отсутствия) преступления, а также виновности (или невиновности) лица, в отношении которого осуществляется производство по уголовному делу, нуждается в существенной корректировке и пересмотре доктринальных положений с учетом информационных технологий. Более активное применение электронных технических средств позволит осуществить электронное уголовно-процессуальное доказывание, тем самым модернизировать всю систему уголовного судопроизводства и решить ряд накопившихся проблем.

Реализацию идеи электронного сопровождения уголовного судопроизводства в России можно представить по трем основным направлениям:

- утверждение приоритетности электронной информационно-сигнальной модели уголовно-процессуального доказывания;

- разработка законодательных правил по работе с электронным уголовным делом;

- внедрение в судебную практику программного обеспечения вынесения приговора с использованием математического моделирования и алгоритмизации принятия решений в виде «электронного помощника».

Прокомментируем каждое из указанных направлений.

Для многих не секрет, что информационный подход в настоящее время является одним из доминирующих методов получения и использования знаний [5, с. 306]. Его поддерживают многие ученые. Так, по мнению Ф.Н. Фаткуллина, информация - это та база, на основе которой устанавливаются и осмысливаются обстоятельства (факты), выясняемые в ходе уголовного процесса [6, с. 6]. А.А. Давлетов считает, что информация - это сообщение, сигнал, имеющий 
своего потребителя и способный удовлетворить ту или иную его потребность, т.е. выполняющий определенную функцию [7, с. 31]. А.Р. Белкин представляет информацию в качестве сведений о событии как предмете доказывания [8, с. 119]. Понятие «информация» в содержание доказательства включают и другие авторы [9-11].

УПК РФ содержит ряд норм, определяющих процессуальные отношения через их информационную составляющую. Однако российский законодатель не связывает напрямую информацию и доказательства. Более прогрессивным в этом плане выглядит положение п. 23 ст. 3 УПК Грузии, согласно которому доказательства - это информация, представленная в суд в установленном законом порядке, содержащие эту информацию предметы, документы, вещи или иные объекты, на основе которых стороны в суде подтверждают или отрицают факты, дают им правовую оценку, выполняют обязанности, защищают свои права и законные интересы, а суд устанавливает наличие или отсутствие факта или деяния, ввиду которого осуществляется уголовный процесс, совершение или несовершение этого деяния определенным лицом, его виновность либо невиновность, а также обстоятельства, влияющие на характер и степень ответственности обвиняемого, характеризующие его личность.

Сущностное определение информации в уголовном процессе основывается на осознании субъектом познания требований, предъявляемых уголовно-процессуальным законом к содержанию доказательств и способам их получения, а также сведений о преступлении, и реализуется с момента восприятия субъектом информации, поступающей в устной, письменной, электронной и других формах передачи сигнала. Исследование информационно-сигнальной природы электронных доказательств в уголовном процессе позволяет различать физический уровень электронно-цифровых следов и информацию, определяемую субъектом уголовнопроцессуального познания как имеющую значение для уголовного дела. Преобразование электронного сигнала в данные, пригодные для восприятия человеком, происходит с помощью специальных программ. Информация, полученная и проверенная в порядке, установленном уголовно-процессуальным законом, может стать доказательством. Так просматривается некая последовательность: электронно-цифровой сигнал - информация - электронное доказательство.
Для того чтобы судебно-следственная практика обрела электронное уголовное дело, требуется внедрить электронный документооборот в уголовное судопроизводство. С этой целью необходимо:

- законодательно закрепить и детально регламентировать фиксацию проведения любого процессуального действия (включая поступление заявления о преступлении, производство следственных действий, осуществление судебного заседания, составление и объявление приговора и т.д.) с помощью электронных технических средств;

- активно развивать электронные средства обеспечения доказывания по уголовным делам (проведение процессуальных действий в досудебном производстве и судебных заседаний в режиме удаленного доступа участника уголовного судопроизводства; электронная защита свидетелей, потерпевших и иных участников уголовного процесса и иные меры в электронном формате; широкое применение электронных средств контроля и т.д.);

- широко использовать электронную подпись.

Электронное уголовное дело может успешно заменить бумажное, традиционное [12, с. 144]. Это позволит: улучшить качество расследования, снизит риск возможной фальсификации доказательств; облегчит проверку материалов уголовного дела руководителями подразделений и органов, прокурором; сократит документооборот, а значит, и сроки расследования; облегчит процедуру ознакомления с материалами уголовного дела; обеспечит сохранность материалов уголовного дела.

Интерес в рассматриваемом аспекте представляют некоторые положения Упк Украины. Согласно п. 2 ч. 1 ст. 103 данного закона, процессуальные действия в ходе уголовного производства могут фиксироваться на носители информации, на котором с помощью технических средств зафиксированы процессуальные действия. В случае фиксирования процессуального действия во время досудебного расследования с помощью технических средств об этом указывается в протоколе. Если с помощью технических средств фиксируется допрос, текст показаний может не вноситься в соответствующий протокол при условии, что ни один из участников следственного действия не настаивает на этом. В таком случае в протоколе отмечается, что показания зафиксированы на носителе информации, который прилагается к нему (ч. 2 ст. 104 УПК Украины). Фиксирование с помощью технических средств уголовного производства в суде является обязательным (ч. 4 ст. 107 УПК Украины). 
В Российской Федерации это не является обязательным. Согласно п. 18 постановления Пленума Верховного Суда РФ «Об открытости и гласности судопроизводства и о доступе к информации о деятельности судов» от 13 декабря 2012 г. № 35, при наличии технической возможности судам надлежит осуществлять фиксацию хода судебного разбирательства с использованием средств аудиозаписи и иных технических средств, а в случае недостаточной вместимости зала судебного заседания, в котором проводится слушание дела, осуществлять в здании суда трансляцию хода судебного заседания в режиме реального времени с применением технических средств. Материалы фиксации хода судебного разбирательства, осуществляемого судом (например, носитель аудиозаписи), приобщаются к делу ${ }^{1}$.

В соответствии с указанным постановлением, а также Федеральным законом «О Судебном департаменте при Верховном Суде Российской Федерации» от 8 января 1998 г. № 7-Ф3, Гражданским процессуальным кодексом Российской Федерации, Уголовно-процессуальным кодексом Российской Федерации, Кодексом административного судопроизводства Российской Федерации в целях обеспечения открытости и гласности судопроизводства в судах разрабатывается регламент применения систем аудиовидеофиксации хода судебных заседаний. Например, в Псковском городском суде Псковской области имеется такой документ, в котором подробно расписывается порядок применения электронных технических средств. При этом фиксацию судебных действий на электронные носители следовало бы осуществлять по всем уголовным делам в обязательном порядке вместо бумажного ведения протокола. Некоторые из этих положений могли бы занять достойное место в УПК РФ. Вот некоторые из них.

«...Фиксация хода судебных заседаний с применением технических средств может проводиться... с использованием иных штатных звукозаписывающих средств, имеющихся в распоряжении суда, с соблюдением требований процессуального законодательства...».

«...При завершении судебного заседания с применением комплекса АФ (АВФ) или иных технических средств секретарем судебного заседания осуществляется остановка аудио- или аудиовиде-

${ }^{1}$ Об открытости и гласности судопроизводства и о доступе к информации о деятельности судов : постановление Пленума Верхов. Суда РФ от 13 дек. 2012 г. № 35 // Российская газета. 2012. 19 дек. озаписи, сохранение записи на жесткий диск комплекса АФ (АВФ) (или сохранение записи иных технических средств на жестом диске компьютера)...».

«...Ознакомление с записями осуществляется в специально оборудованных (или иных - на усмотрение суда) помещениях в присутствии сотрудника аппарата суда на технических средствах, принадлежащих суду».

«...Копия записи АФ (АВФ) судебного заседания участникам судопроизводства производится на основании письменного заявления, подаваемого председательствующему судье либо председателю суда...».

«...Запись осуществляется на носитель, предоставляемый заявителем после его форматирования и проверки на наличие вредоносных программ и вирусов, о чем заявитель должен быть предупрежден при принятии заявления на выдачу копии записей...»².

Следственные действия в ходе досудебного производства по уголовным делам могли бы также фиксироваться на электронные носители информации. Для этого в кабинетах следователей было бы необходимо установить стационарные цифровые видеокамеры. А если следственное действие проводится вне кабинета следователя, то приглашается специалист. В таких случаях электронная техническая запись может осуществляться как на цифровую видеокамеру, так и на смартфон хорошего качества. В УПК следовало бы подробно регламентировать процедуры создания, накопления и хранения электронных записей, выполненных процессуальных действий, а также порядка ознакомления с ними.

Хотелось бы также заметить, что на законодательном уровне не решены частные вопросы по уже существующим информационным технологиям. Так, УПК РФ акцентирует внимание на изъятии электронных носителей информации и недостаточно регулирует вопросы копирования электронной информации. В юридической литературе при обсуждении данных вопросов ситуация сохраняется [13; 14]. Вместе с тем на практике изъятие электронных носителей все чаще создает трудности для хозяйствующих субъектов и физических лиц ${ }^{3}$. Поэтому требуется более детальная проработка процедуры копирования электрон-

\footnotetext{
${ }^{2}$ URL: http://pskovskygor.psk.sudrf.ru/modules.php? name $=$ docum_sud\&rid $=37$.

3 Решение Арбитражного суда города СанктПетербурга и Ленинградской области по делу № A56640/2013 [Электронный ресурc]. URL: http://base. garant.ru/41122724.
} 
ной информации с учетом прав и законных интересов владельцев и пользователей электронных носителей.

Кроме того, для решения вопроса об электронном документообороте в уголовном судопроизводстве необходимо признать электронную информацию как самостоятельный вид доказательств [15, с. 9], что позволит рассматривать электронный документ как разновидность данного доказательства. Практика использования электронного документа в арбитражном процессе известна и может быть успешно внедрена в уголовное судопроизводство. Вопросы использования электронной подписи активно обсуждаются за рубежом. В частности, Дж. Хантли обращает внимание на то, что выражение «электронная подпись», объединив подпись в качестве компонента для формализации письменных документов и подписи в качестве гарантии идентичности, порождает множество нерешенных проблем в законе [16].

Уже сегодня на практике известны случаи, когда электронная подпись, применяемая при совершении финансовых операций, становится предметом рассмотрения в рамках уголовного дела.

Так, «приговором Центрального районного суда г. Челябинска гр. Богомолова и гр. Копытин К.В. признаны виновными в том, что группой лиц по предварительному сговору путем обмана с использованием платежной карты покушались на хищение денежных средств в крупном размере.

Рассмотрев апелляционные жалобу и представление, судебная коллегия установила, что суд обоснованно признал достоверными показания гр. Богомоловой, данные в судебном заседании, подробно изложенные в приговоре, согласно которым, работая в должности бухгалтера по расчетам и уполномоченная совершать операции по расчетному счету организации по приему-передаче информации, электронных документов, имея умысел, направленный на хищение денежных средств с использованием платежных карт, она 22 апреля 2011 года оформила 2 платежных поручения и перечислила денежные средства на расчетные счета платежных карт, номера которых ей сообщил соучастник, удостоверив данные платежные поручения имеющейся у нее электронной цифровой подписью. С целью скрыть следы преступления она умышленно установила флеш-карту на свой компьютер и ввела вирусную программу. Деньги не были зачислены на одну из платежных карт и были возвращены, поскольку она не указала фамилию владельца карты в платежном поручении. Остальные денежные средства были перечислены на карту и получены соучастником, который распорядился ими по своему усмотрению»".

Несомненно, реализация идеи электронного уголовно-процессуального доказывания потребует усилий многих ученых и специалистов. Представляется целесообразным сформировать в рамках процессуальной науки отдельное направление, систематизирующее существующие ИТ-технологии и адаптирующее их для достижения процессуальных целей. Законодательство, в свою очередь, должно своевременно реагировать на достижения науки и техники, нормативно отражать их результаты. Все это позволит правоохранительным органам эффективно отвечать на современные вызовы преступности.

Идея вынесения приговора с использованием математических методов и алгоритмизации принятия судебных решений не нова и имеет как сторонников, так и противников. О необходимости использования в юриспруденции математических методов и алгоритмов говорилось достаточно давно, задолго до современного развития информационных технологий. К сторонникам данного направления развития юридической науки и практики следует отнести следующих ученых: А.А. Арямов [17], С.И. Дементьев [18], Д.С. Дядькин [19], В.И. Курляндский [20], Н.Д. Оранжиреев [21], С.Г. Ольков [22], Ajit Narayanan и Marvyn Bennun [23] и др. Не углубляясь в конкретные разработки математических методов назначения наказаний и обобщив их принципиальные подходы, можно выделить такие направления: балльная система; шкалирование; выстраивание отношений с помощью математических формул.

Безусловно, что у компьютеризации и алгоритмизации принятия судебных решений много и противников. Против математических методов назначения уголовных наказаний выступают такие ученые, как С.А. Велиев [24], И.М. Гальперин [25], А.Ф. Мицкевич [26] и др. Высказываясь против математики в праве, Т.В. Непомнящая отмечает, что общим недостатком теории применения математических методов при назначении наказаний является то, что, «удалившись в совещательную комнату для вынесения приговора,

${ }^{4}$ Дело № 10-159/2014. Апелляционное постановление Судебной коллегии по уголовным делам Челябинского областного суда // Архив Челябинского областного суда. 
судья должен будет производить сложнейшие математические расчеты. А ведь в таком случае не исключена возможность арифметической ошибки!» [27, с. 57]. Думается, что с учетом современного уровня развития информационных технологий и компьютеризации всех сфер профессиональной деятельности арифметическая ошибка под наблюдением профессионального судьи будет сведена к минимуму.

Авторы по данному вопросу предлагают компромиссный вариант, когда специальная программа по математическому моделированию и алгоритмизации принятия судебных решений должна предлагать судье «оптимальный» с учетом заложенных критериев приговор, который будет иметь для него рекомендательное и ориентирующее значение.

Вместе с тем следует заметить, что в настоящее время при вынесении судебных решений отмечается высокий уровень субъективизма и человеческого фактора. Одно и то же дело при рассмотрении у разных судей с высокой долей вероятности может быть разрешено поразному. По этому поводу С.Г. Ольков отмечает, что «продвинутое» человечество, как и в «далекие» средние века, выносит судебные приговоры «по внутреннему убеждению и совести судей» без серьезных измерений и глубинного анализа сути дела!.. До сих пор, как и сотни лет назад, «истина рождается в споре», а не в ходе серьезных научных изысканий» [28, с. 153].

Кроме того, в ходе принятия судебных решений нередки и логические ошибки. Использование логических методов, оформленных в математические формулы, позволит обеспечить точность в процессе правового регулирования и выработки оптимального судебного решения. В этой связи мы разделяем позицию Т.В. Кашаниной, отмечающей, что «судебная деятельность - это познавательная деятельность, которая, безусловно, осуществляется в логической форме... Нелогичность же может проявляться не только в композиции текста судебного акта (это не самое страшное), но и в неправильной квалификации, неудачной аргументации и обосновании принятого решения, что уже может повлечь серьезные последствия... Логика представляет собой общий метод рассуждения, технику мышления, носящую универсальный характер, независимо от рассматриваемого объекта или конкретной науки» [29, с. 32]. Вынесение судебного приговора и назначение наказания - это очень сложная работа, основанная на универсальных правилах рассуждения и мышления, и неприемлемо делать ее «по наитию».

Не на должном уровне, на наш взгляд, поднимается проблема верификации судебных решений в целом и приговоров в частности, т.е. теоретико-познавательной обоснованности и удостоверения истинности информации, содержащейся в них. По мнению В.Я. Колдина, существует подмена информационно-содержательного анализа правоприменительной деятельности формально-процедурным подходом в связи с исключением принципа истины из числа указанных в законе принципов процесса. А отсюда следует, что «принятие правового решения почти исключительно сводится к процедуре вынесения приговора» [30, с. 43].

Известно, что санкции уголовно-правовых норм формулируются в УК в относительно определенной форме с достаточно широкими пределами судейского усмотрения. Это обстоятельство признается в том числе противниками применения математических методов в юриспруденции. По этому поводу Т.В. Непомнящая отмечает, что «судейское усмотрение все еще остается достаточно широким, в связи с чем необходимо говорить о необходимости его упорядочения. И достигаться это может, в частности, дальнейшей формализацией наказания» $[27$, с. 55].

Проблема освободить судью при вынесении приговора от усмотрения является краеугольным камнем системы уголовного правосудия в странах общего права. Ряд авторов создали информационную систему наказаний для предоставления судьям юридических, фактических и статистических данных. Цель системы не лишить судью своего усмотрения, но лучше информировать его и таким образом добиться согласованности подходов по всей юрисдикции. В их работе на конкретных примерах показано, как применяется такая информационная система [31, р. 99].

Кроме того, в качестве аргумента за алгоритмизацию процесса вынесения итоговых судебных решений при назначении наказаний следует учитывать Федеральный закон «Об антикоррупционной экспертизе нормативных правовых актов и проектов нормативных правовых актов» от 17 июля 2009 г. № 172-Ф35, который устанавливает правовые и организационные основы антикоррупционной экспертизы нормативных правовых актов и проектов нормативных правовых актов в целях выявле-

\footnotetext{
${ }^{5}$ Российская газета. 2009. 22 июля.
} 
ния в них коррупциогенных факторов и их последующего устранения. Соответствие УК РФ с его «широкими» относительно определенными санкциями данному антикоррупционному закону вызывает большие сомнения. Например, согласно санкции ч. 1 ст. 126 УК РФ, похищение человека наказывается принудительными работами на срок до пяти лет либо лишением свободы на тот же срок. В данном случае суд «волен» в выборе санкции от двух месяцев до пяти лет вышеуказанных видов наказания, учитывая весьма оценочные, «размытые» и не конкретные «универсальные» для всех видов и размеров санкций правила назначения наказания. Что это, если не коррупциогенный фактор в виде широких пределов усмотрения правоприменителя?

Поэтому назрела необходимость смещения акцентов в установлении истинности и правосудности приговора с процессуальной стороны на содержательную с объективными, научно обоснованными критериями его вынесения с применением математических методов.

По нашему мнению, при дальнейшей разработке «точной юриспруденции» перспективы практического применения в праве имеют следующие математические методы: математического программирования; принятия решений при многих критериях; статистического моделирования; проверки статистических гипотез; дискриминантного и кластерного анализа; теории игр и исследования операций; применения нечетких моделей на базе нечеткой логики; актуарной математики и теории риска; многомерного статистического анализа; определения оптимальных параметров юридической модели; численные методы и др.
Соглашаясь в целом с позицией М.Ф. Маликова, следует отметить, что математические методы и компьютерные программы вынесения приговора необходимо постоянно совершенствовать с учетом новейших достижений юридических, общественных наук и наук о человеке. Должен проводиться системный анализ последствий вынесенных судебных приговоров с точки зрения совершенствования алгоритмов их вынесения [32, с. 72].

Привлечение математических методов обработки больших массивов информации возможно по следующим направлениям:

- влияние вынесенных судебных решений на восстановительную (компенсаторную) функцию права;

- выявление региональных особенностей вынесения приговоров и соотношение их с принципом законности;

- оценка эффективности приговоров по конечному результату их действия с точки зрения ценности и полезности.

Представляется, что дальнейшее исследование правовой действительности поможет сформировать объективную систему определения эффективности вынесенных судебных решений, своевременно и оперативно корректировать алгоритм, используемый при вынесении этих решений, в том числе и судебного приговора. По нашему мнению, основанная на объективных математических и логических законах «специальная программа» позволит судье точнее и профессиональнее выполнять свою работу по принятию и вынесению судебных решений, безусловно, с учетом внутреннего «человеческого» убеждения в его справедливости.

\section{СПИСОК ИСПОЛЬЗОВАННОЙ ЛИТЕРАТУРЫ}

1. Протасевич А.А. Криминалистическая характеристика компьютерных преступлений / А.А. Протасевич, Л.П. Зверянская // Российский следователь. - 2013. - № 11. - С. 45-47.

2. Goodman M. International Dimensions of Cybercrime / M. Goodman // Cybercrimes: A Multidisciplinary Analysis / S. Ghosh, E. Turrini (eds). - Berlin : Heidelberg, 2010. - 361 p.

3. Smith R.G. Cyber Criminals on Trial / Russell G. Smith, Peter Grabosky, Gregor Urbas // International Journal of Law and Information Technology. - 2012. - Vol. 20 (3). - P. 242-245.

4. Nissan E. Legal Evidence, Police Intelligence, Crime Analysis or Detection, Forensic Testing, and Argumentation: An Overview of Computer Tools or Techniques / E. Nissan // International Journal of Law and Information Technology. - 2009. - Vol. 17 (1). - P. 1-82.

5. Краткий обзор ИТ-технологий, используемых в юридической деятельности / Р.Г. Драпезо, О.Д. Сергеев, Е.В. Жариков, Н.А. Быванцев // Вестник Кемеровского государственного университета. - 2013. - № 1. - С. 306-312.

6. Фаткуллин Ф.Н. Общие проблемы процессуального доказывания / Ф.Н. Фаткуллин. - Казань : Изд-во Каз. ун-та, 1973. -176 c.

7. Давлетов А.А. Основы уголовно-процессуального познания / А.А. Давлетов. - Екатеринбург : Гуманитар. ун-т, 1997. - 190 с.

8. Белкин А.Р. Теория доказывания в уголовном судопроизводстве / А.Р. Белкин. - М. : Норма, 2007. - 633 с.

9. Ларин А.М. Уголовный процесс России. Лекции-очерки / А.М. Ларин, Э.Б. Мельникова, В.М. Савицкий ; под ред. В.М. Савицкого. - М. : БЕК, 1997. - 314 с.

10. Гущин А.Н. Оценка доказательств и оперативно-розыскной информации при уголовно-процессуальном доказывании / А.Н. Гущин, Ю.В. Франциферов, Н.А. Громов // Следователь. - 2001. - № 1. - С. 4-11. 
11. Краснова Л.Б. Электронные носители информации как вещественные доказательства / Л.Б. Краснова // Известия Тульского государственного университета. Экономические и юридические науки. - 2013. - № 4-2. - С. 254-260.

12. Мещерякова О.А. Организационно-процессуальные меры предупреждения утраты уголовных дел в системе профилактики преступности / О.А. Мещерякова // Юридический вестник Дагестанского государственного университета. 2015. - T. 14, № 2. - С. 141-145.

13. Васюков В.Ф. Изъятие электронных носителей информации при расследовании преступлений: нерешенные проблемы правового регулирования и правоприменения / В.Ф. Васюков, А.В. Булыжкин // Российский следователь. - 2016. № $6 .-$ C. 3-8.

14. Козловский П.В. Участие специалиста в изъятии электронных носителей / П.В. Козловский, П.В. Седельников // Научный вестник Омской академии МВД России. - 2014. - № 1 (52). - С. 17-19.

15. Овсянников Д.В. Копирование электронной информации как средство уголовно-процессуального доказывания : автореф. дис. ... канд. юрид. наук : 12.00 .09 / Д.В. Овсянников. - Екатеринбург, 2015. - 21 с.

16. Huntley J. Electronic Signatures, Law and Regulation, by Lorna Brazell (Thomson/Sweet \& Maxwell, 2004), 550 pages / John Huntley // International Journal of Law and Information Technology. - 2007. - Vol. 15, iss. 2. - P. 227-229.

17. Арямов А.А. Общетеоретические основы учения об уголовном наказании : дис. ... д-ра юрид. наук : 12.00 .08 / А.А. Арямов. - СПб., 2004. -288 с.

18. Дементьев С.И. Уголовное наказание: содержание, виды, назначение, исполнение / С.И. Дементьев, Р.А. Дьяченко, А.И. Трахов. - Краснодар : Изд-во Юж. ин-та менеджмента, 2000. - 311 с.

19. Дядькин Д.С. Теоретические основы назначения уголовного наказания: алгоритмический подход / Д.С. Дядькин. СПб. : Юрид. центр Пресс, 2006. - 508 с.

20. Курляндский В.И. Уголовная политика, дифференциация и индивидуализация уголовной ответственности / В.И. Курляндский // Основные направления борьбы с преступностью. - М. : Юрид. лит., 1975. - С. 77-95.

21. Оранжиреев Н.Д. Преступление и наказание в математической зависимости / Н.Д. Оранжиреев. - М. : Типо-литогр. Т-ва Кушнеров и К, 1916. - 69 с.

22. Ольков С.Г. Биосоциальная механика, общественная патология и точная юриспруденция / С.Г. Ольков. - Новосибирск : Наука, 1999. - 391 с.

23. Law, Computer Science, and Artificial Intelligence / ed. by Ajit Narrayanan, Marvyn Bennun. - Intellect Books, 1998. - 288 p.

24. Велиев С.А. Принципы назначения наказания / С.А. Велиев. - СПб. : Юрид. Центр Пресс, 2004. - 388 с.

25. Гальперин И.М. Правосудие и арифметика / И.М. Гальперин // Известия. - 1986. - 15 авг.

26. Мицкевич А.Ф. Уголовное наказание: понятие, цели и механизмы действия / А.Ф. Мицкевич. - СПб. : Юрид. Центр Пресс, 2005. - 450 c.

27. Непомнящая Т.В. Формализация назначения наказания / Т.В. Непомнящая // Вестник Сибирского института бизнеса и информационных технологий. - 2015. - № 2. - С. 55-60.

28. Ольков С.Г. О справедливом приговоре / С.Г. Ольков // Библиотека криминалиста. - 2014. - № 6 (17). - С. 151-156.

29. Кашанина Т.В. Логика как элемент юридической техники / Т.В. Кашанина // Журнал российского права. - 2008. № 2. - С. 25-35.

30. Колдин В.Я. Верификация правовых решений / В.Я. Колдин // Вестник Московского университета. Сер. 11, Право. 2012. - № 1. - C. 42-52.

31. Informing the discretion: the sentencing information system of the judicial commission of New South Wales / I. Potas, D. Ash, M. Sagi, S. Cumines, N. Marsic // International Journal of Law and Information Technology. - 1998. - Vol. 6 (2). - P. 99-124.

32. Маликов М.Ф. Ретроспективный анализ судебного приговора / М.Ф. Маликов // Евразийская адвокатура. - 2014. № 1. - C. 71-74.

\section{REFERENCES}

1. Protasevich A.A. Criminalistic characteristics of computer crimes. Rossiiskii sledovatel' $=$ Russian Investigator, 2013, no. 11, pp. 45-47. (In Russian).

2. Goodman M. International Dimensions of Cybercrime. In Ghosh S., Turrini E. (eds). Cybercrimes: A Multidisciplinary Analysis. Berlin, Heidelberg, 2010. 361 p.

3. Smith R.G., Grabosky P., Urbas G. Cyber Criminals on Trial. International Journal of Law and Information Technology, 2012, no. 20 (3), pp. 242-245.

4. Nissan E. Legal Evidence, Police Intelligence, Crime Analysis or Detection, Forensic Testing, and Argumentation: An Overview of Computer Tools or Techniques. International Journal of Law and Information Technology, 2009, no. 17 (1), pp. 1-82.

5. Drapezo R.G., Sergeev O.D., Zharikov E.V., Byvantsev N.A. A brief overview of IT used in legal work. Vestnik Kemerovskogo gosudarstvennogo universiteta $=$ Bulletin of Kemerovo State University, 2013, no. 1, pp. 306-312. (In Russian).

6. Fatkullin F.N. Obshchie problemy protsessual'nogo dokazyvaniya [General Issues of Procedural Proofing]. Kazan University Publ., 1973. 176 p.

7. Davletov A.A. Osnovy ugolovno-protsessual'nogo poznaniya [Basics of Criminal Procedure Investigation]. Yekaterinburg, University for Humanities Publ., 1997. 190 p.

8. Belkin A.R. Teoriya dokazyvaniya v ugolovnom sudoproizvodstve [Theory of Proofing in Criminal Court Procedures]. Moscow, Norma Publ., 2007. 633 p.

9. Larin A.M., Mel'nikova E.B., Savitskii V.M.; Savitskii V.M. (ed.). Ugolovnyi protsess Rossii. Lektsii-ocherki [Criminal Process in Russia. Lecture Essays]. Moscow, BEK Publ., 1997. 314 p.

10. Gushchin A.N., Frantsiferov Yu.V., Gromov N.A. Evaluation of proofs and investigation of information in criminal procedure proofing. Sledovatel' = Investigator, 2001, no. 1, pp. 4-11. (In Russian). 
11. Krasnova L.B. Electronic storage devices as material evidence. Izvestiya Tul'skogo gosudarstvennogo universiteta. Ekonomicheskie i yuridicheskie nauki = Bulletin of Tula State University. Economic and Legal Sciences, 2013, no. 4-2, pp. 254-260. (In Russian).

12. Meshcheryakova O.A. Organizational and procedural measures of preventing the loss of criminal cases in the system of crime prevention. Yuridicheskii vestnik Dagestanskogo gosudarstvennogo universiteta = Law Herald of Dagestan State University, 2015, vol. 14, no. 2, pp. 141-145. (In Russian).

13. Vasyukov V.F., Bulyzhkin A.V. Seizure of electronic storage devices in crime investigation: unsolved problems of legal regulation and law enforcement. Rossiiskii sledovatel' = Russian Investigator, 2016, no. 6, pp. 3-8. (In Russian).

14. Kozlovskii P.V., Sedel'nikov P.V. Participation of a specialist in the seizure of electronic storage devices. Nauchnyi vestnik Omskoi akademii MVD Rossii = Research Bulletin of Omsk Academy of Russian Ministry of the Interior, 2014, no. 1 (52), pp. 17-19. (In Russian).

15. Ovsyannikov D.V. Kopirovanie elektronnoi informatsii kak sredstvo ugolovno-protsessual'nogo dokazyvaniya. Avtoref. Kand. Diss. [Copying electronic information as a method of criminal law proofing. Cand. Diss. Thesis]. Yekaterinburg, 2015. 21 p.

16. Huntley John. Electronic Signatures, Law and Regulation, by Lorna Brazell (Thomson/Sweet \& Maxwell, 2004$), 550$ pages. International Journal of Law and Information Technology, 2007, vol. 15, iss. 2, pp. 227-229.

17. Aryamov A.A. Obshcheteoreticheskie osnovy ucheniya ob ugolovnom nakazanii. Dokt. Diss. [General theoretical basis of criminal punishment. Doct. Diss. Thesis]. Saint Petersburg, 2004. 288 p.

18. Dement'ev S.I, D'yachenko R.A., Trakhov A.I. Ugolovnoe nakazanie: soderzhanie, vidy, naznachenie, ispolnenie [Criminal Punishment: Content, Types, Execution]. Krasnodar, Uzhny Institute of Management Publ., 2000. 311 p.

19. Dyad'kin D.S. Teoreticheskie osnovy naznacheniya ugolovnogo nakazaniya: algoritmicheskii podkhod [Theoretical Basis of Criminal Sentencing: an Algorithmic Approach]. Saint Petersburg, Yuridicheskii Tsentr Press Publ., 2006. 508 p.

20. Kurlyandskii V.I. Criminal policy, differentiation and individualization of criminal liability. Osnovnye napravleniya bor'by s prestupnost'yu [Key Directions of Crime Counteraction]. Moscow, Yuridicheskaya literatura Publ., 1975, pp. 77-95. (In Russian).

21. Oranzhireev N.D. Prestuplenie i nakazanie v matematicheskoi zavisimosti [Crime and Punishment in Mathematical Dependence]. Moscow, Tipo-Litografiya Tovarishchestva Kushnerov i K Publ., 1916. 69 p.

22. Ol'kov S.G. Biosotsial'naya mekhanika, obshchestvennaya patologiya i tochnaya yurisprudentsiya [Biosocial Mechanics, Public Pathology and Exact Jurisprudence]. Novosibirsk, Nauka Publ., 1999. 391 p.

23. Ajit Narrayanan, Marvyn Bennun (eds). Law, Computer Science, and Artificial Intelligence. Intellect Books, 1998.288 p.

24. Veliev S.A. Printsipy naznacheniya nakazaniya [Principles of Sentencing]. Saint Petersburg, Yuridicheskii Tsentr Press Publ., 2004. 388 p.

25. Gal'perin I.M. Justice and Arithmetics. Izvestiya, 1986, August 15. (In Russian).

26. Mitskevich A.F. Ugolovnoe nakazanie: ponyatie, tseli i mekhanizmy deistviya [Criminal Punishment: Concept, Goals and Mechanisms]. Saint Petersburg, Yuridicheskii Tsentr Press Publ., 2005. 450 p.

27. Nepomnyashchaya T.V. Formalization of sentencing. Vestnik Sibirskogo instituta biznesa i informatsionnykh tekhnologii = Bulletin of Siberian Institute of Business and Information Technologies, 2015, no. 2, pp. 55-60. (In Russian).

28. Ol'kov S.G. On a just sentence. Biblioteka kriminalista = Library of a Criminalist, 2014, no. 6 (17), pp. 151-156. (In Russian).

29. Kashanina T.V Logics as an element of legal technique. Zhurnal rossiiskogo prava = Journal of Russian Law, 2008, no. 2, pp. 25-35. (In Russian).

30. Koldin V.Ya. Verification of legal decisions. Vestnik Moskovskogo universiteta. Seriya 11, Pravo = Bulletin of Moscow State University. Series 11, Law, 2012, no. 1, pp. 42-52. (In Russian).

31. Potas I., Ash D., Sagi M., Cumines S., Marsic N. Informing the discretion: the sentencing information system of the judicial commission of New South Wales. International Journal of Law and Information Technology, 1998, vol. 6 (2), pp. 99-124.

32. Malikov M.F. The retrospective analysis of court sentence. Evraziiskaya advokatura = Eurasian Advocacy, 2014, no. 1, pp. 71-74. (In Russian).

\section{ИНФОРМАЦИЯ ОБ АВТОРАХ}

Зуев Сергей Васильевич - заведующий кафедрой правоохранительной деятельности и национальной безопасности Южно-Уральского государственного университета (национального исследовательского университета), доктор юридических наук, доцент, г. Челябинск, Российская Федерация; e-mail: zuevsergej@inbox.ru.

Никитин Евгений Владимирович - доцент кафедры правоохранительной деятельности и национальной безопасности Южно-Уральского государственного университета (национального исследовательского университета), кандидат юридических наук, г. Челябинск, Российская Федерация; e-mail: 79193651790@yandex.ru.

\section{ДЛЯ ЦИТИРОВАНИЯ}

Зуев С.В. Информационные технологии в решении уголовно-процессуальных проблем / С.В. Зуев, Е.В. Никитин // Всероссийский криминологический журнал. 2017. - T. 11, № 3. - C. 587-595. - DOI: 10.17150/25004255.2017.11(3).587-595.

\section{INFORMATION ABOUT THE AUTHORS}

Zuev, Sergey V. - Head, Chair of Law Enforcement and National Security, South Ural State University (National Research University), Doctor of Law, Ass. Professor, Chelyabinsk, the Russian Federation; e-mail: zuevsergej@ inbox.ru.

Nikitin, Evgeny V. - Ass. Professor, Chair of Law Enforcement and National Security, South Ural State University (National Research University), Ph.D. in Law, Chelyabinsk, the Russian Federation; e-mail: 79193651790@yandex.ru.

\section{FOR CITATION}

Zuev S.V., Nikitin E.V. Information technologies in solving criminal procedure problems. Vserossiiskii kriminologicheskii zhurnal = Russian Journal of Criminology, 2017, vol. 11, no. 3, pp. 587-595. DOI: 10.17150/25004255.2017.11(3).587-595. (In Russian). 